\title{
MORPHOMETRIC ANALYSES OF DOLINES - THE PROBLEM OF DELINEATION AND CALCULATION OF BASIC PARAMETERS
}

\author{
MORFOMETRIČNE ANALIZE VRTAČ - PROBLEM DOLOČANJA \\ OBODA IN RAČUNANJA OSNOVNIH PARAMETROV
}

\author{
Ela ŠEGINA ${ }^{1, *}$, Čedomir BENAC ${ }^{2}$, Josip RUBINIĆ ${ }^{3} \&$ Martin KNEZ $^{4}$
}

\begin{abstract}
UDC 551.448:514.113.6(497.572)

Ela Šegina, Čedomir Benac, Josip Rubinić \& Martin Knez: Morphometric analyses of dolines - the problem of delineation and calculation of basic parameters

So far reported unstable correlations between environmental settings and doline geometry require a revision of doline delineating methods and morphometric analyses that follows from such input data. We examine the reliability of the most accessible data sources for doline delineation, namely basic topographic maps at a scale of 1:5,000 and ortho-rectified aerial photographs (digital orthophotos) of $0.5 \mathrm{~m}$ resolution. Their reliability has been quantified in the Dinaric karst (Krk Island, NE Adriatic Sea). The adequacy of most commonly used morphometric parameters (viz. elongation and circularity) and their variations applied in previous studies are mathematically verified and practically tested. The simulation of an individual method behaviour performed on polygons with increasing circularity and elongation demonstrated their ranges of validity. The efficiency of a particular method was verified by the application to the real dataset of dolines. The optimal variation of an individual parameter (circularity $=P c c / P d$; elongation $=\varepsilon$ of the best fitting ellipse) is identified and suggested for use in order to provide uniform results and increase the comparability of future morphometric analyses. Asymmetry (the distance between the centroid of doline ground plan and the centroid of the largest inscribed circle) as an additional parameter for describing doline ground plans has been developed and is proposed for further use.
\end{abstract}

Key words: karst, doline delineating, morphometric analyses, measurement errors, Krk Island.
Izvleček

UDK 551.448:514.113.6(497.572)

Ela Šegina, Čedomir Benac, Josip Rubinić \& Martin Knez: Morfometrične analize vrtač - problem določanja oboda in računanja osnovnih parametrov

Nezanesljivost korelacij med okoljskimi dejavniki in geometrijo vrtač je spodbudila pregled do sedaj uporabljenih metod določanja oboda vrtač in primernosti morfometričnih analiz, ki sledijo iz teh podatkov. V prispevku preverjamo zanesljivost najširše dostopnih podatkovnih virov za določanje oboda vrtač, in sicer topografskih kart v merilu $1: 5000$ in ortofotov z ločljivostjo $0,5 \mathrm{~m}$. Zanesljivost smo določali na primeru Dinarskega krasa (otok Krk, SV Jadransko morje). Primernost do sedaj najpogosteje uporabljenih parametrov (tj. sploščenost in krožnost) in njunih različic, ki se pojavljajo v literaturi, smo matematično preverili in preizkusili pri realnem naboru vrtač. Simulacija delovanja posamezne metode na poligonih $\mathrm{z}$ naraščajočo krožnostjo in sploščenostjo je pokazala njihova območja veljavnosti. Učinkovitost metod smo nato preverili še pri realnem vzorcu vrtač, pri katerem smo ugotovili, katera je najprimernejša različica posameznega parametra (krožnost $=P c c / P d$; sploščenost $=$ $\varepsilon$ prilegajoče elipse), in jo, da bi zagotovili večjo usklajenost in primerljivost rezultatov, predlagali za nadaljnjo rabo v prihodnjih morfometričnih analizah vrtač. Kot dodaten parameter za analizo tlorisa vrtač smo razvili in preizkusili indeks asimetrije oboda vrtač, tj.razdaljo med težiščem tlorisa vrtače in težiščem največjega včrtanega kroga.

Ključne besede: kras, določanje oboda vrtač, morfometrične analize, merske napake, otok Krk.

\footnotetext{
${ }^{1}$ Miklošičeva 4a, 1230 Domžale, Slovenia, e-mail: ela.segina@gmail.com

${ }^{2}$ Faculty of Civil Engineering, University of Rijeka, R. Matejčić 3, 51000 Rijeka, Croatia, e-mail: cbenac@gradri.uniri.hr

${ }^{3}$ Faculty of Civil Engineering, University of Rijeka, R. Matejčić 3, 51000 Rijeka, Croatia, e-mail: jrubinic@uniri.hr

${ }^{4}$ Karst research institute ZRC SAZU, Titov trg 2, 6230 Postojna, Slovenia, e-mail: knez@zrc-sazu.si

* Corresponding author
}

Received/Prejeto: 14.02 .2017 


\section{INTRODUCTION}

Even though certain global conditions of doline formation related to climate, elevation, slope inclination, lithology, and tectonics have been successfully established (Gams 2000), on a regional scale, correlations between the geometry of dolines and environmental factors have often been quite variable or even weak. It was hoped that morphometric studies would reveal direct links between karst landforms and processes, but they have not satisfactory fulfilled such expectations (Day \& Chenoweth 2013). Due to rapid data processing, its applicability to extensive and inaccessible areas, and its apparent objectivity, the use of remote sensing data in Geographic Information System (GIS) is proving a very promising method in geomorphology. However, its objectivity is subject to the scale employed, the use of correct algorithms, the interpreter's subjectivity, and possible measurement and drawing errors.

The importance and the problem of doline upper rim definition have already been discussed by several authors (Bondesan et al. 1992; Šušteršič 1994; Ćalić 2009; Telbisz et al. 2009). Even though being the most reasonable definition of doline perimeter, a principle of "an abrupt change in surface slope" (Šušteršič 1994) has seldom been used in practice due to its fieldwork requirements (Basso et al. 2013). Instead, the focus has been directed towards simplification and automation of the procedure. Previously, the most frequently used methods for doline upper rim delineation involved the use of topographic maps of various scales based on the assumption that the uppermost closed contour properly represents the doline perimeter (Bauer 2015; Denizman 2003; Telbisz et al. 2009). Recently, the delineation of dolines has become increasingly focused on automating delineation using digital elevation models (DEMs), combining DEMs and satellite imagery, or combining DEMs and diverse algorithms (e. g., Bauer 2015; Carvalho Júnior et al. 2014; Obu \& Podobnikar 2013; Pardo-Igúzquiza et al., 2013; Telbisz et al. 2016).

Besides the question of doline spatial extent, the main obstacle in morphometric analyses of dolines is their irregular geometry. The demand for a certain amount of generalization required for further morphometric analyses has led to several approaches which were applied without mathematical examination of their adequacy. Various parameters have been applied especially on the basis of doline upper rim (listed in Bondesan et al. 1992). Among them, two basic parameters for describing the perimeter shape of dolines, circularity and elongation, have been the most commonly employed (e.g., Basso et al. 2013; Bauer 2015; Denizman 2003; Plan \& Decker 2006; Doctor \& Young 2013; Carvalho Júnior et al. 2014; Kobal et al. 2014), but due to the variants of the parameters, the results from different places are difficult to compare.

Circularity describes the irregularity of doline planar shape and defines its deviation from the perfect circle. The morphometric analyses in karst research applying circularity of doline upper rim mostly do not surpass an acquisition of rough results only. Due to the general tendency of dolines toward centricity, the deviation in circularity is theoretically expected to reveal the local differences in "doline-forming" processes, impure karst conditions or underground basis of contemporary doline shaping. Elongation describes the extension of doline planar shape in a particular direction. It is a dual-aspect parameter that describes the degree of elongation and its orientation. It is mostly presumed that its value correlates with a structural predisposition.

Asymmetry has seldom been applied as a parameter for doline investigation. It may provide an insight into regional factors of spatially or quantitatively non-uniform removal of karst material such as lithological heterogeneity, local tectonic stress, ecological and microclimatic factors, etc. It has been previously calculated as a quotient between slope lengths in certain directions from the deepest point of a doline (Bárány \& Mezõsi 1991), a method that is unsuitable for sediment-bottomed dolines where the deepest point is not possible to determine superficially.

Due to the unsatisfactory results of doline morphometric studies acquired so far, a discussion on method reliability is required. Difficulties may arise at every stage of data processing: 1) doline definition, 2) doline detection, 3) doline delineation, and 4) the use of suitable parameters in morphometric calculations. In this study, we focus on the issue of doline's planar shape definition (3) and the use of suitable parameters (4). It is expected that improved delineation methods or at least awareness of their deficiencies, and the use of appropriate mathematical operations will contribute to the uniformity of morphometric analyses and lead towards more stable correlations between landforms and processes on karst.

\section{METHODS AND TEST SITE}

The delineating errors have been identified on the karst relief of Krk Island $\left(367 \mathrm{~km}^{2}\right)$ characterized by different vegetation types. Morphometric parameters have been tested on a smaller sample of dolines (Fig. 1, Tab. 1) located in a forested area, where preliminary observations indicated the smallest deviations in defining doline shapes (see also paragraph 4.1). All parameters were processed with ArcGIS 10.2 software. 


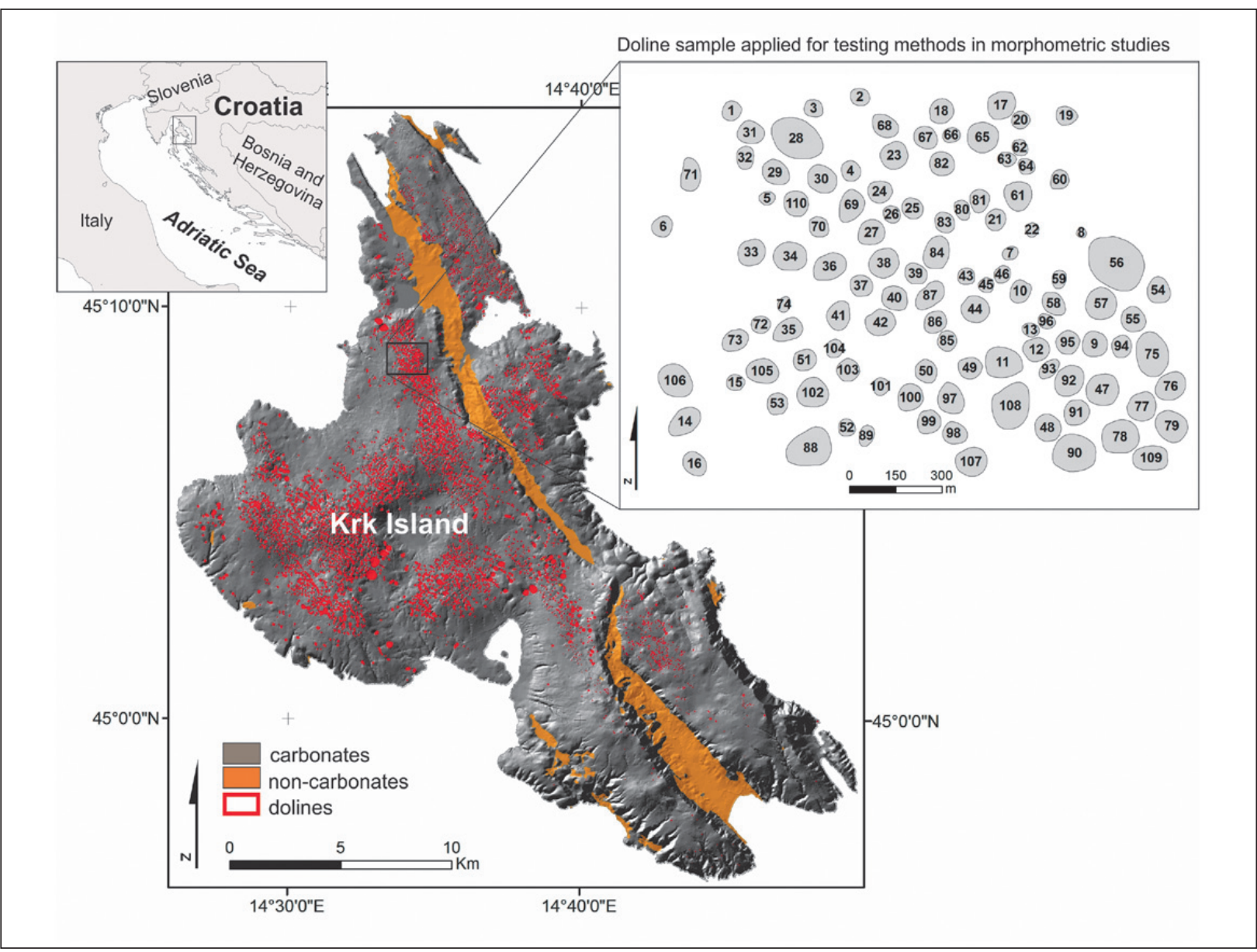

Fig. 1: Location map of Krk Island, Croatia, with doline distribution and location of the doline dataset used in testing morphometric parameters. DEM: State Geodetic Administration of Croatia, 2004. Geological map modified from Benac et al. (2013).

Tab. 1: Basic statistics of measured parameters for a total of 110 dolines.

\begin{tabular}{|c|c|c|c|c|}
\hline Total of 110 dolines & Min. & Max. & Mean & St. dev. \\
\hline$P d-$ doline perimeter $(\mathrm{m})$ & 93.87 & 496.12 & 224.39 & 64.33 \\
\hline$A d-$ an area of a doline ground plan $\left(\mathrm{m}^{2}\right)$ & 701.17 & 19586.63 & 4336.07 & 2676.00 \\
\hline
\end{tabular}

On topographic maps at a scale of 1:5,000 the upper rim corresponded to upper closed contour. On ortho-rectified aerial photographs (digital orthophotos or DOFs) at resolution $0.5 \mathrm{~m}$, the upper rim followed visual changes in surface representation that are connected to change in surface slope (shadow effect, change in vegetation). Additionally, upper rims of four dolines located on different vegetation types were determined on-field by the principle of "the abrupt change in surface slope" (Šsusteršič 1994). Upper rims were obtained by the use of conventional GPS of the app. $3 \mathrm{~m}$ position error, where reference points representing the perimeter of the doline were measured at the interval of $10 \mathrm{~m}$ along the rim. By field examination on bare karst surface dolines of any size can be detected - the limiting factor of field recogni- tion is the depth of the depression which enables distinguishing the doline from other surface irregularities.

We examined four existing methods for describing circularity and four for describing elongation of a doline planar shape (Tab. 2, Fig. 2). In addition to already published methods, we generated and tested the circularity as a deviation of the doline perimeter from the largest inscribed circle (Pd/Pic) (circularity method 5).

A new method has been formulated to determine the degree and the direction of doline planar shape asymmetry (Tab. 2, Fig. 2). The distance between doline's ground plan centroid $(C d)$ and the centroid of the largest inscribed circle $(\mathrm{Cic})$ indicates the degree of asymmetry, while the orientation of the connecting line between $\mathrm{Cd}$ and $\mathrm{Cic}$ determines the direction of doline asymmetry. 
Tab. 2: Tested methods for calculating doline morphometric characteristics.

\begin{tabular}{|c|c|c|c|}
\hline Parameter & & Method & Cited or employed in \\
\hline \multirow[t]{5}{*}{ Circularity index (IC) } & 1 & $P c c / P d$ (Fig. 2 a) & Bondesan et al. 1992 \\
\hline & 2 & $P d / P c$ (Fig. 2 b) & $\begin{array}{l}\text { Denizman 2003; } \\
\text { Doctor \& Young } 2013\end{array}$ \\
\hline & 3 & $4 \pi^{*}\left(A d / P d^{2}\right)$ & Carvalho Júnior et al. 2014 \\
\hline & 4 & $A d /\left(\pi(2 * A d / P d)^{2}\right)$ & Kobal et al. 2014 \\
\hline & 5 & Pd/Pic (Fig. $2 \mathrm{c}$ ) & generated in this study \\
\hline \multirow[t]{4}{*}{ Elongation index } & 1 & $\begin{array}{l}\text { the longest axis/the longest perpendicular axis of } \\
\text { the ground plan (Fig. } 2 \mathrm{~d} \text { ) }\end{array}$ & $\begin{array}{l}\text { Ćalić } 2009 \\
\text { Kobal et al. } 2014\end{array}$ \\
\hline & 2 & $\begin{array}{l}2 a / 2 b \text { ratio of an ellipse with equal planimetric area } \\
\text { and momentum of equal interia to a doline ground } \\
\text { plan (Fig. } 2 \text { e) }\end{array}$ & Šušteršič 1994 \\
\hline & 3 & $\begin{array}{l}\text { doline perimeter/perimeter of a circle with an } \\
\text { equivalent area (Fig. } 2 \mathrm{f} \text { ) }\end{array}$ & Plan \& Decker 2006 \\
\hline & 4 & $\begin{array}{l}\text { numerical eccentricity } \varepsilon \text { as a measure of ellipse } \\
\text { elongation calculated for the standard deviation } \\
\text { ellipse (Fig. } 2 \text { g) }\end{array}$ & Doctor \& Young 2013 \\
\hline $\begin{array}{l}\text { Degree of asymmetry } \\
\text { Direction of asymmetry }\end{array}$ & & $\begin{array}{l}|C d C i c|(\text { Fig. } 2 \mathrm{~h}) \\
\text { the orientation of } C d C i c \text { (Fig. } 2 \text { h) }\end{array}$ & $\begin{array}{l}\text { generated in this study } \\
\text { generated in this study }\end{array}$ \\
\hline
\end{tabular}

$P d$ - doline perimeter

$A d-$ an area of a doline ground plan

$P c c$ - circumference of the circumscribed circle

$P c$ - the perimeter of a circle of the equivalent area

$\mathrm{Pic}$ - the perimeter of the largest inscribed circle

$C d$ - doline's ground plan centroid (an arithmetic mean point of all the points in the shape)

Cic - centroid of the largest inscribed circle

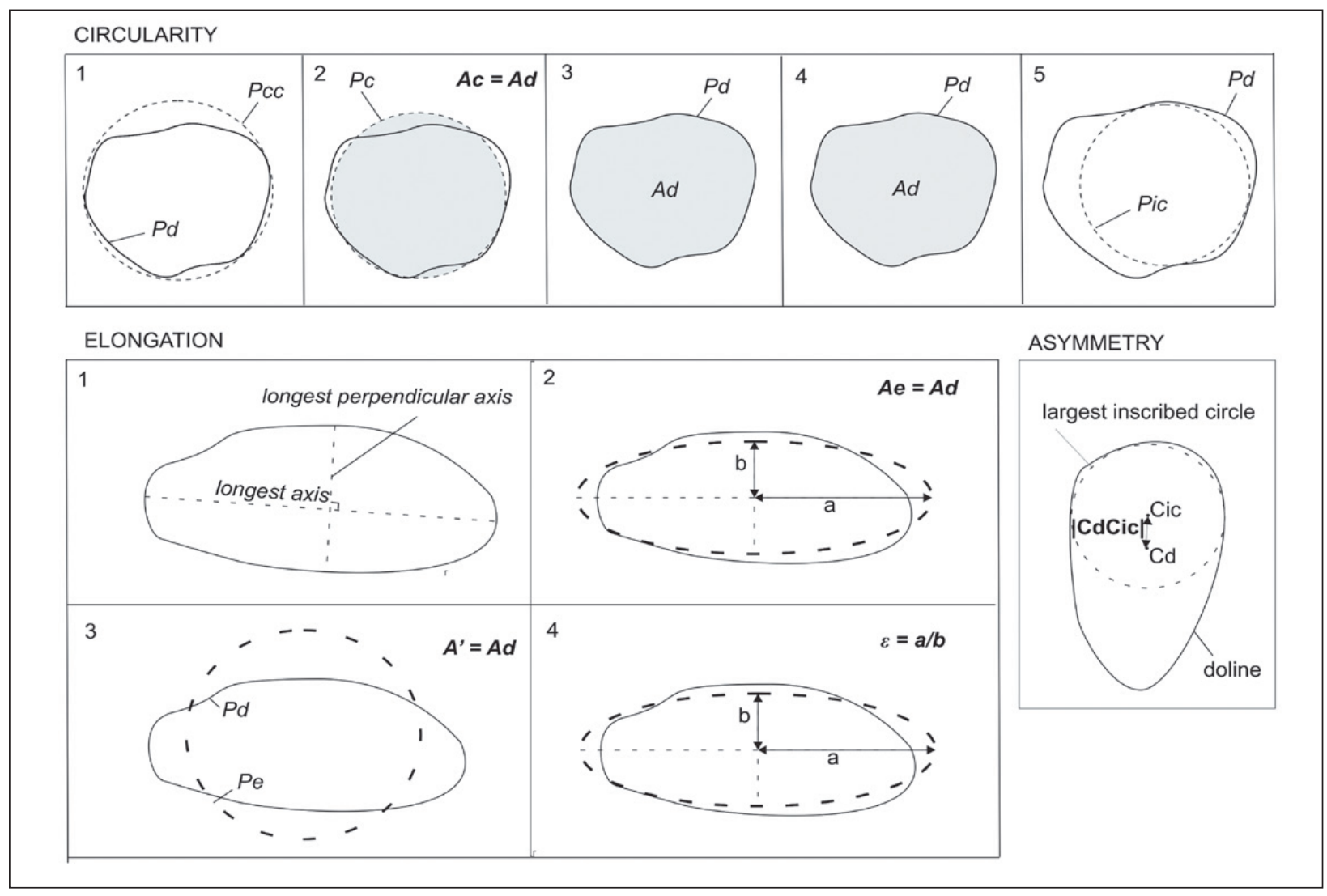

Fig. 2: Measured parameters employed at testing basic doline morphometric characteristics. 


\section{RESULTS AND DISCUSSION}

\section{DOLINE DELINEATION}

The main obstacle for the consistent description of doline planar shapes is the irregularity of their perimeters and insufficient scale of data sources applied for their delineation. Limitations of determining doline upper rims have been defined for procedures based on contour concept (topographical maps, but also common procedures of upper rim extraction from DEMs), visual determination from DOFs and field determination (Tab. 3).

Procedures based on contour concept (topographical maps, automatic extraction from DEMs) are unsuccessful when the doline upper rim varies in altitude (Fig. $3 \mathrm{a}, \mathrm{b})$ and when contour interval is too wide to capture actual doline upper rim (Fig. 3 c). Field examination on the test site indicates that even dolines located on a flat surface with rims that are not touching each other are bounded by the vertically irregular rim.

Procedures based on the visual determination from orthophotos are highly dependent on vegetation. They are successful only where a shadow effect or significant change of vegetation due to change in slope inclination is visible (Fig. 4).

Even though field examination is expected to be a most reliable method for doline upper rim determination, it is nevertheless subject to several limitations as inaccessibility, indistinctness of doline upper rim, and GPS error. In case of dense vegetation, the upper rim obtained by GPS could be even less reliable than the one extracted from topographical maps, DOFs or DEMs.

Tab. 3: Limitations of doline upper rim determination methods.

\begin{tabular}{|lll|}
\hline Limitations of topographic maps & $\begin{array}{l}\text { Doline upper rim is characterized by } \\
\text { irregular altitude. }\end{array}$ & $\begin{array}{l}\text { Doline upper rim occupies an alti- } \\
\text { tude within a contour interval. }\end{array}$ \\
\hline Limitations of orthophotos & $\begin{array}{l}\text { Doline is covered by vegetation that } \\
\text { does not produce a shadow effect. }\end{array}$ & \\
\hline Limitations of field determination & $\begin{array}{l}\text { Doline upper rim is hardly determin- } \\
\text { able due to the absence of an abrupt } \\
\text { change of slope. }\end{array}$ & $\begin{array}{l}\text { Doline upper rim is inaccessible } \\
\text { due to dense vegetation. }\end{array}$ \\
\hline
\end{tabular}

a)

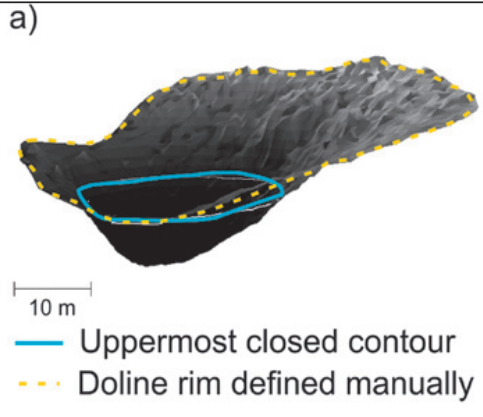

b)

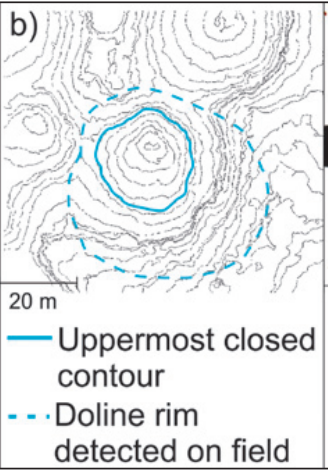

c) 1
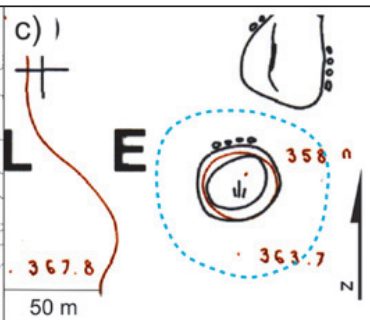

- Uppermost closed contour

- . Doline rim detected on field

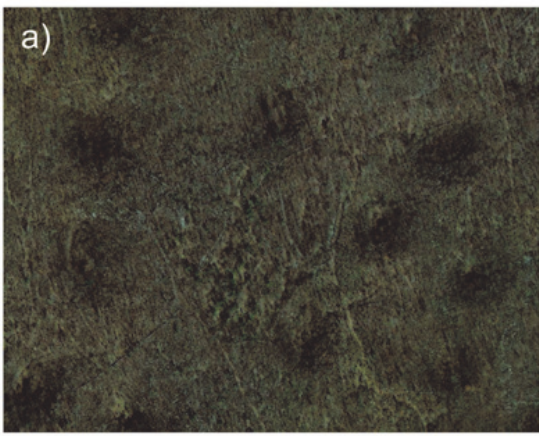

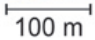

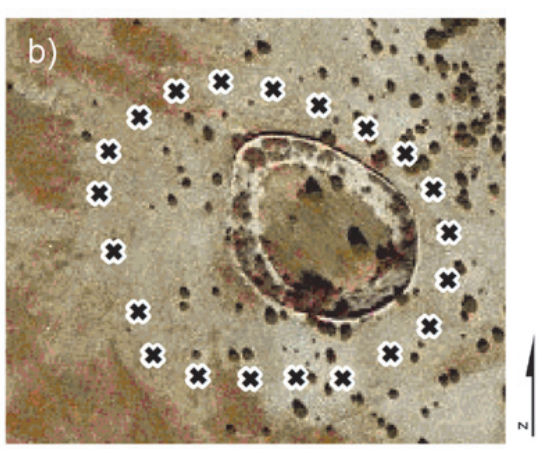

$\longmapsto 20 \mathrm{~m} \quad \boldsymbol{x}$ upper rim determined on field
Fig. 3: a) Doline upper rim manually extracted from DEM based on high-resolution $L i D A R$ data and the doline upper rim extracted from DEM by common procedures, following the uppermost contour concept. The upper rim elevation in case of particular doline vertically varies for even $8 \mathrm{~m}$. b) Doline representation on the topographical map: uppermost closed contour vs. doline perimeter defined on the field. c) Doline perimeter acquired on field occupies an altitude within a contour interval.

Fig. 4: a) Example of well-visible dolines upper rims on the forested surface and b) invisible upper rim on bare karst due to the absence of shadow effect. The upper rim was determined on the field with GPS measurements at the interval of $10 \mathrm{~m}$. 


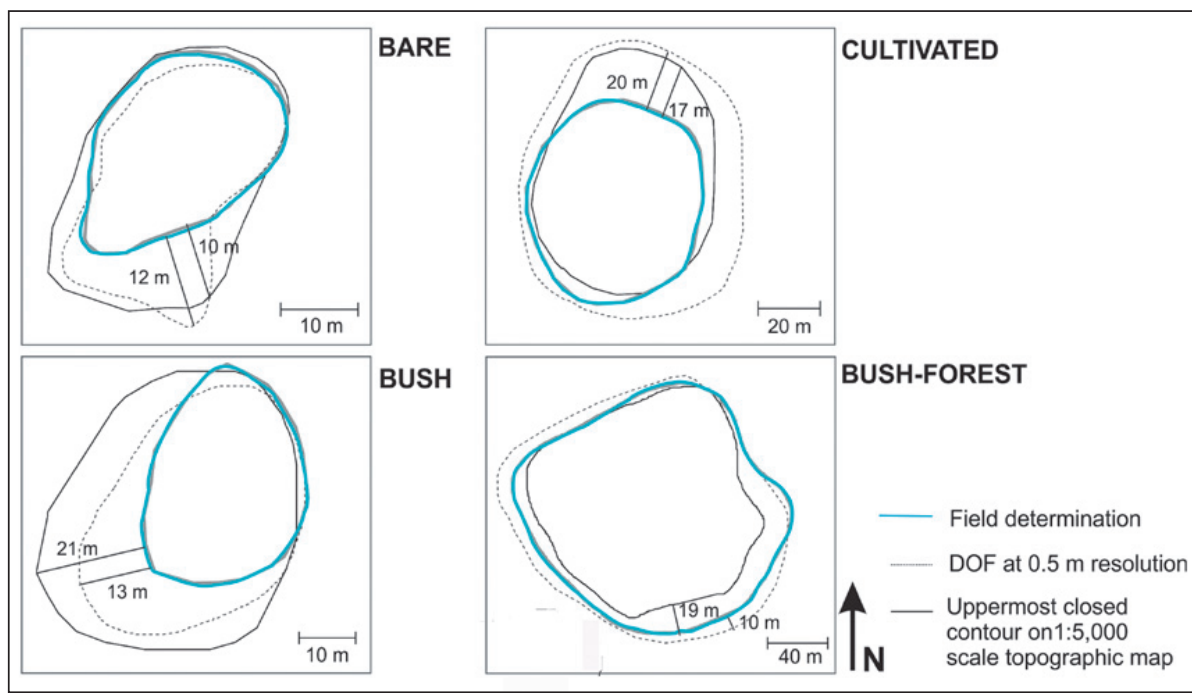

Fig: 5: Comparison of doline delineation methods on examples from areas with different vegetation types.

There is no single approach that would work optimally in all circumstances. However, it was established that perimeters defined by orthophotos correspond very well to the actual rims determined by the field survey, but it is only true when the shadow effect is present. While location errors due to GPS positioning are negligible, digitized data are subject to shape and especially noticeable size errors (Fig. 5). Other vegetation types as bare karst land and areas covered by bushes and coniferous trees could be reliably mapped only by field survey.

We are witnessing the expansion of methods for automated doline delineation and numerous tests of their reliability (Doctor \& Young 2013; Bauer 2015; Obu \& Podobnikar 2013; Pardo-Igúzquiza et al. 2013; Carvalho Júnior et al. 2014; Kobal et al. 2015; Telbisz et al. 2016). The effort is put in the increase of input data resolution, but the issue never considered is that such methods still follow "the contour principle" instead of actual doline upper rim. Field examination and comparison of different methods show that vertical irregularity of doline upper rim results in considerable shape and especially size deviations. Due to the vertical irregularity of doline upper rim, the automation of doline delineation using even high-resolution DEMs remains an unsolved issue.

\section{CIRCULARITY}

The simulation of an individual method behaviour performed on polygons with decreasing circularity (from $\mathrm{n}$-angles convex polygon (circle) towards irregular concave polygon) (Fig. 6 a) shows that for the convex shapes, the method Pcc/Pd (1) define the circularity with the highest precision among all analyzed methods. In case of highly irregular (concave) polygons this ratio produces false results but as dolines are sub-circular in a planar shape, this is not a matter in issue. The range of method's validity is behind the applicability of the method in karst studies. The ratio $4 \pi^{\star} \mathrm{Ad} / P d^{2}$ (3) is a reciprocal of the ratio $A d / \pi\left(2^{\star} A d / P d\right)^{2}(4)$ and both give results comparable to the ratio $P d / P c$ (2). However, application to the real dataset of dolines (Fig. $6 \mathrm{~b}$ ) did not allow the recognition of any region of validity for these three ratios. The ratio $P d / P i c$ (5) distinguishes between concave and convex polygons but is not as effective in distinguishing among sub-circular shapes (see the result for an 8-angles convex polygon in Fig. 6 a) as the method $P c c / P d$ (1).

Choosing the most appropriate index thus primarily depends on a doline's planar shape geometry and the purpose of the morphometric analyses. For the purpose of describing doline sub-circular planar shape in karstological practice, the ratio $P c c / P d$ (1) provides the most detailed results. However, one must bear in mind that in the presence of highly irregular (concave) shapes, this ratio can produce false results. Spatial representation of a suggested variant of circularity index is presented on a real dataset of 110 dolines (Fig. 7).

\section{ELONGATION}

According to the simulation of an individual method behaviour performed on polygons with increasing elongation (from circle towards increasingly elongated ellipse, and irregular concave polygon), the method (3) recognizes non-elongated but highly irregular shapes as highly elongated shapes (Fig. 8 a). Application to a real data set (Fig. 8 b) demonstrates that method (2) effectively distinguishes highly elongated, while method (4) is more efficient in distinguishing among subcircular shapes. Method (1) gives results similar to method (2), but the irregularity of doline perimeter is in some cases causing false deviations in doline elongation. Methods based on the best-fitting ellipse ((2) 


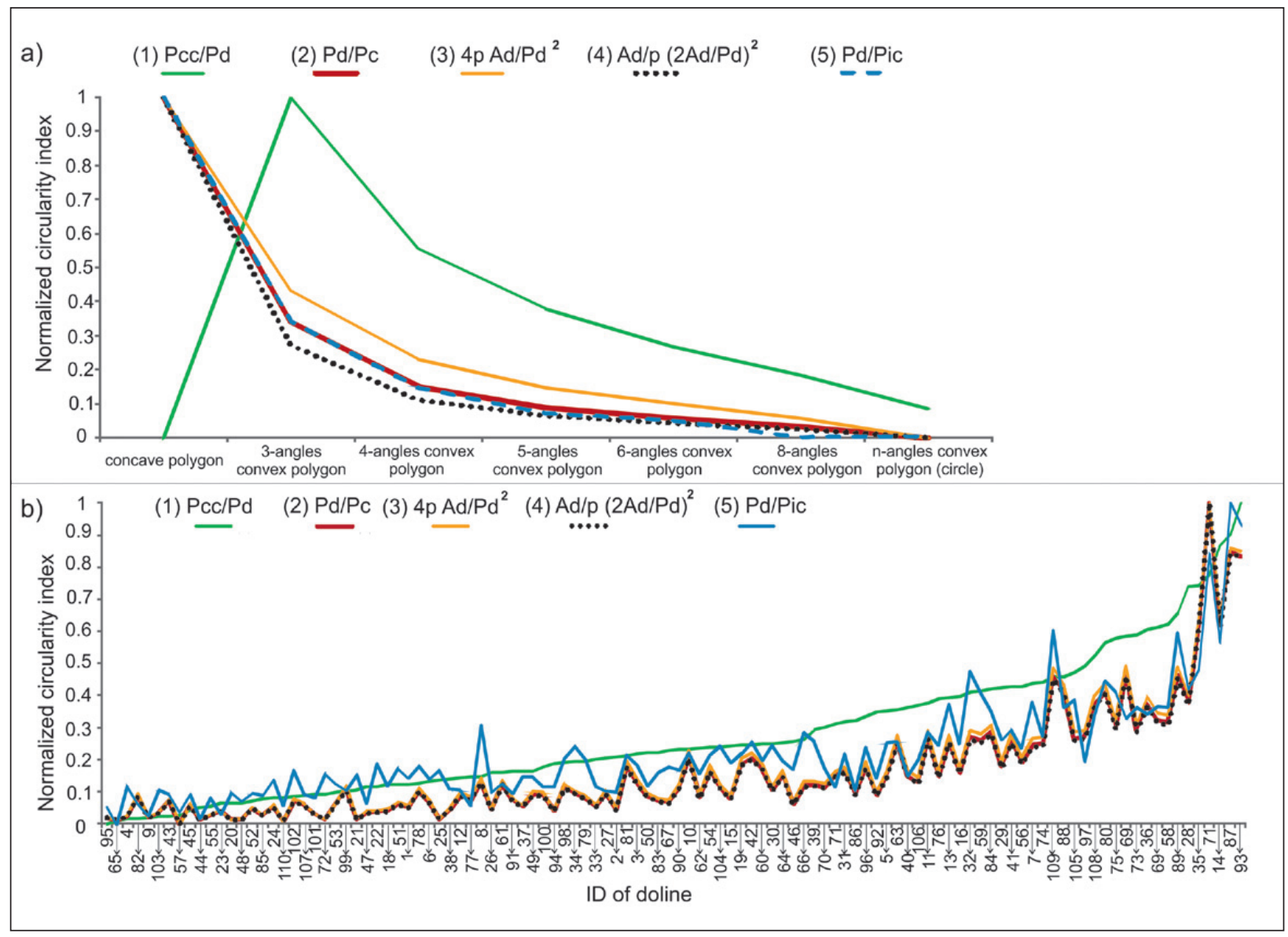

Fig. 6: a) The simulation of methods behaviours performed on polygons with circularity rate decreasing from n-angles convex polygon (circle) towards irregular concave polygon. b) The comparability of calculated circularity indices on the sample of 110 dolines, from most circular $(I D=95)$ to least circular doline (ID = 87) based on the most efficient method for calculating circularity index Pcc/Pd (1).

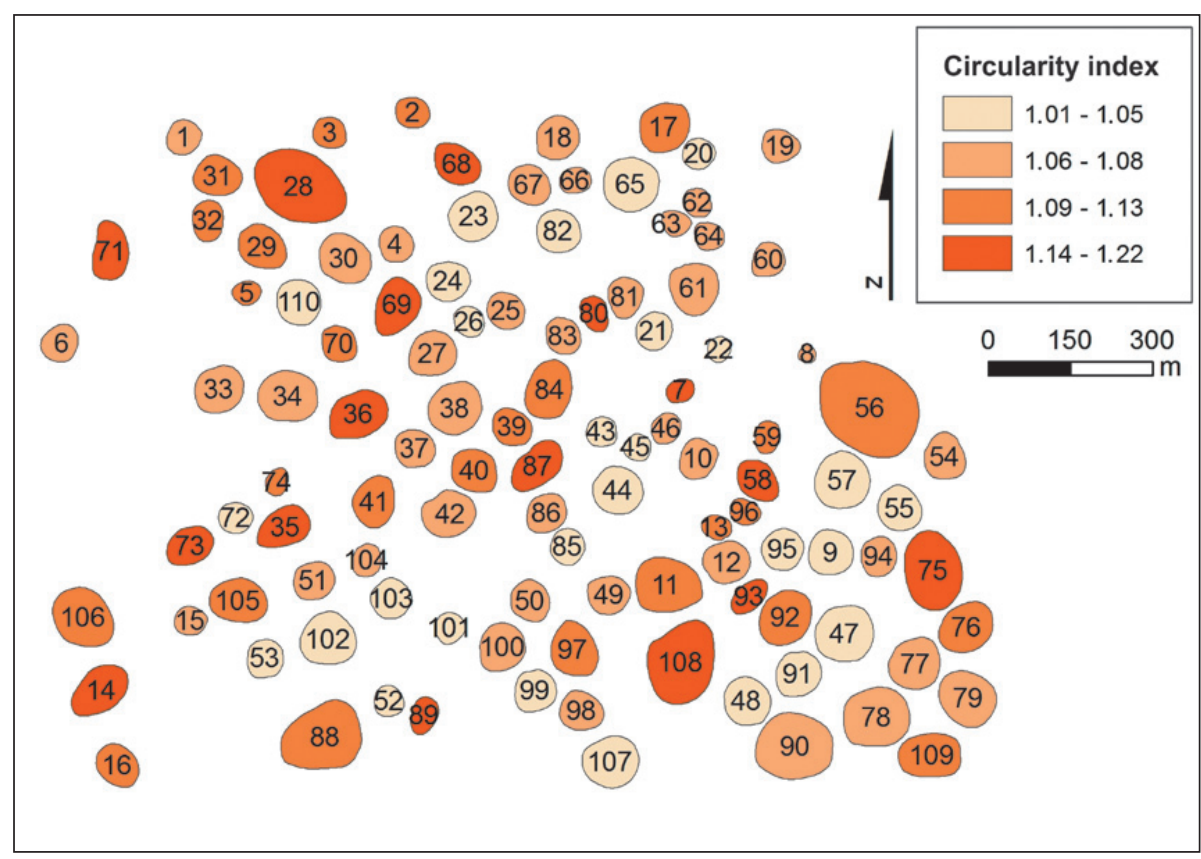

Fig. 7: Spatial representation of a suggested variant of circularity index on a real dataset of 110 dolines. 
a) — longest axis : longest perpendicular axis of ground plan

- doline perimeter : perimeter of a circle with an equivalent area

— numerical eccentricity as a measure of ellipse elongation calculated for the standard deviation ellipse
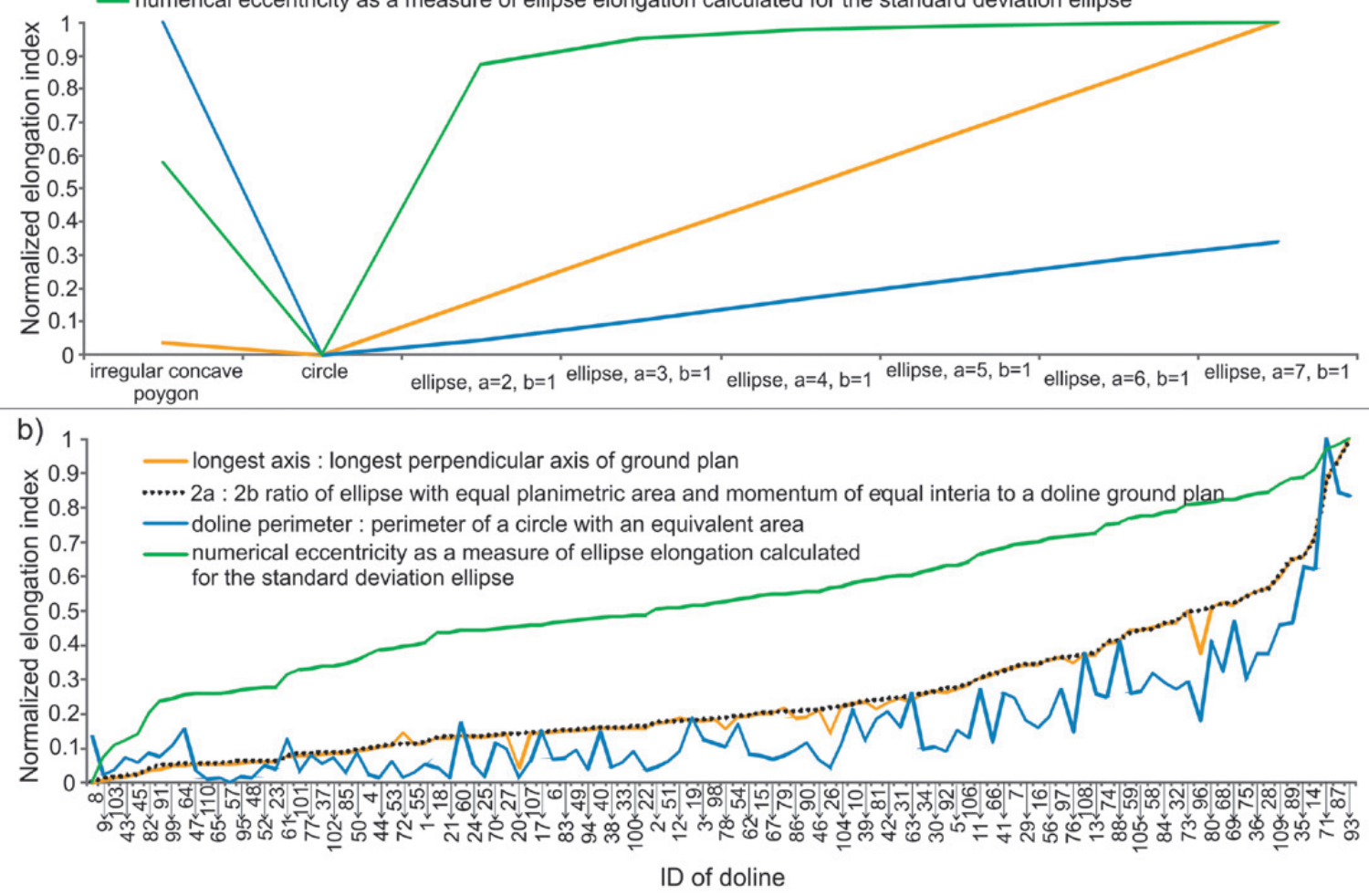

Fig. 8: a) The simulation of methods behaviours performed on polygons with elongation rate increasing from circle towards increasingly elongated ellipse and irregular concave polygon. Note that simulations performed by methods 1 and 2 gives the same results and are both presented with orange line. b) The comparability of calculated elongation indices on the sample of 110 dolines, from least elongated (ID $=8)$ to most elongated doline (ID =87) based on the most efficient method for calculating elongation index $\varepsilon$ of the best-fitting ellipse (4).

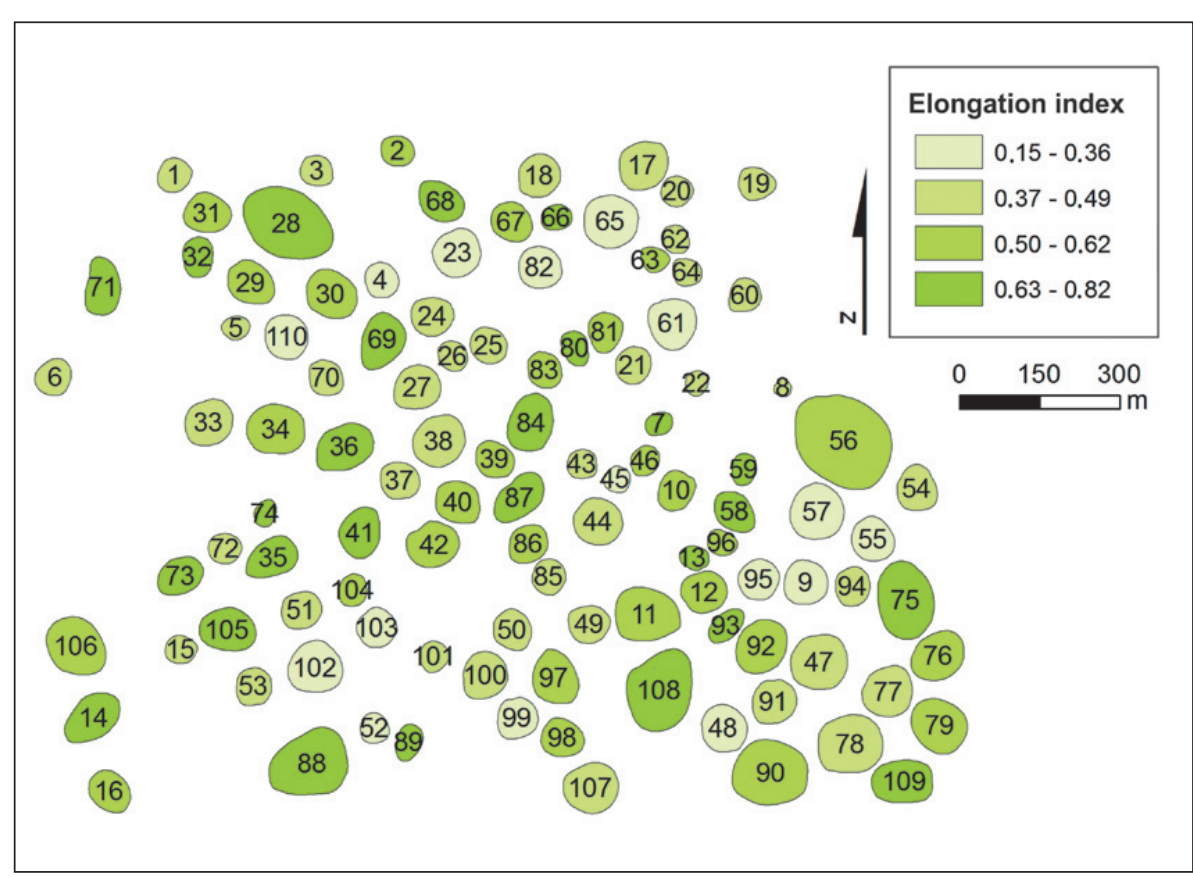

Fig. 9: Spatial representation of a suggested variant of elongation index on a real dataset of 110 dolines. 

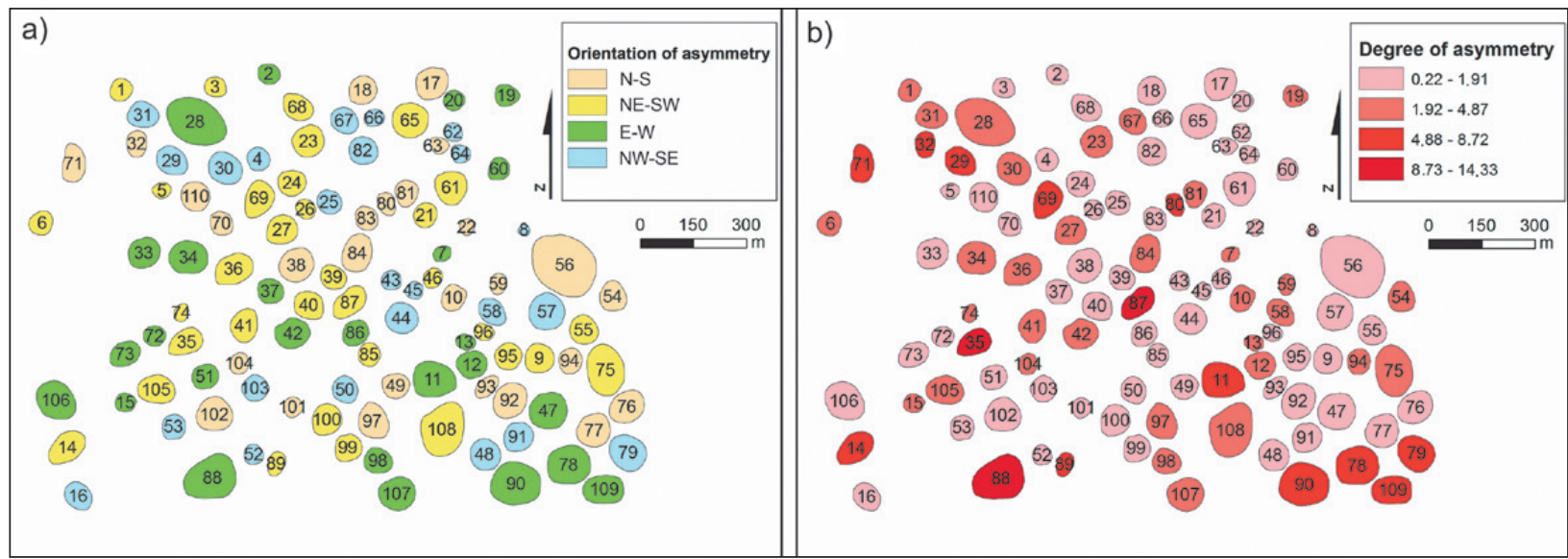

Fig. 10: Spatial representation of asymmetry index on a real dataset of 110 dolines: a) orientation of asymmetry and b) degree of asymmetry.

and (4)), that generalize the irregular planar shape of a doline express its elongation with fewer errors. Due to mainly sub-circular doline planar shapes, the numerical eccentricity $\varepsilon$ as a measure of ellipse elongation calculated for the best fitting ellipse (4) appears to be the most efficient method for determination of doline elongation. Spatial representation of a suggested variant of elongation index is presented on a real dataset of 110 dolines (Fig. 9).

\section{ASYMMETRY}

The newly generated method for quantitative determination of the degree and the direction of asymmetry was applied to the entire sample of 110 dolines (Fig. 10). Inaccuracy in the direction of asymmetry appears in cases where the shape of a doline is approaching subequilateral triangle (dolines $41,54,60,97$ ) or sub-square shapes (doline 64) with several axes of symmetry.

\section{CONCLUSIONS}

The exact extent of the spatial influence of dolines in karst systems is an ongoing topic of research in karstology and is not an issue specifically dealt with here. However, attention was given to the apparently loose and inconsistent doline delineation methods and morphometric analyses applied so far. Conclusions can be summed up in the following points:

Manual delineation using orthophotos is proven to afford a more reliable method for doline delineation than topographic maps and other automated and semi-automated methods using DEMs of any resolution.

Contour-based methods (topographical maps and common procedures for doline upper rim extraction from DEM) are not convenient representation of actual doline upper rim due to the vertical irregularity of doline rim and, in case of topographical maps, due to contour interval that may not capture actual doline perimeter.

In order to direct morphometric studies of dolines toward optimization and comparability on wider scales, a mathematical examination of several commonly used ground plan morphometric parameters was undertaken.
Simulations demonstrated that employed mathematical approaches own different ranges of validity.

For the purpose of describing the circularity of sub-circular planar shapes of dolines the circumference of a circumscribed circle/the perimeter of the doline is the most effective index of circularity. For determining doline elongation, the optimal method is the numerical eccentricity $\varepsilon$ of the best-fitting ellipse.

The degree and direction of asymmetry can be satisfactorily described by the distance between the centroid of the largest inscribed circle and the centroid of the doline ground plan.

After examination of some basic principles of doline upper rim determination, and a review of approaches analyzing the planar shape of dolines presented here, the potential significance of parameters as circularity, elongation and asymmetry could finally be established. The uniform employment of adequate parameters and improved delineation methods would lead to greater accuracy and global comparability of doline morphometric data and promises more stable correlations between forms and processes on karst. 


\section{ACKNOWLEDGEMENTS}

We thank most sincerely France Šušteršič for his general review, discussion on the topic, and fruitful comments, and Tilen Šetina for his mathematical review. The research was partially funded by the Fund of donors for postgraduate studies in Mathematics and Science at the Slovenian Academy of Science and Arts, and by The Slovene Human Resources and Scholarship Fund.

\section{REFERENCES}

Bárány, I. \& G. Mezõsi, 1991: Further morphometrical data from some important Hungarian Karst areas.Proceedings of the Conference on Environmental Changes in Karst Areas. I.G.U.-U.I.S. Quaderni del Dipartimento di Geografia 13. Universita di Padova, Padova, 137-142.

Basso, A., Bruno, E., Parise, M. \& M. Pepe, 2013: Morphometric analysis of sinkholes in a karst coastal area of southern Apulia (Italy).- Environmental Earth Science, 70, 2545-2559. DOI: http://dx.doi. org/10.1007/s12665-013-2297-z

Bauer, C., 2015: Analysis of dolines using multiple methods applied to airborne laser scanning data.Geomorphology, 250, 78-88. DOI: http://dx.doi.org/10.1016/j.geomorph.2015.08.015

Benac, Č., Juračić, M., Matičec, D., Ružić, I. \& K. Pikelj, 2013: Fluviokarst and classical karst: examples from the Dinarics (Krk Island, Northern Adriatic, Croatia).- Geomorphology, 184, 64-73. DOI: http://dx. doi.org/10.1016/j.geomorph.2012.11.016

Bondesan, A., Meneghel, M. \& U. Sauro, 1992: Morphometric analysis of dolines.- International Journal of Speleology, 21, 1-4, 1-55. DOI: http://dx.doi.org/10.5038/1827-806X.21.1.1

Carvalho Júnior, O. A., Guimarães, R. F., Montgomery, D. R., Gillespie, A. R., Gomes, R. A. T., Souza Martins, É. \& N. C. Silva, 2014: Karst Depression Detection Using ASTER, ALOS/PRISM and SRTM-Derived Digital Elevation Models in the Bambuí Group, Brazil.- Remote Sensing, 6, 330-351. DOI: http://dx.doi. org/10.3390/rs6010330

Calić, J., 2009: Uvala - contribution to the study of karst depressions (with selected examples from Dinarides and Carpatho-Balkanides).- $\mathrm{PhD}$ thesis. University of Nova Gorica, Slovenia, pp. 213.

Day, M. \& S. Chenoweth, 2013: Surface roughness of karst landscapes.- In: Shroder, J. (Editor in Chief), Frumkin, A. (Ed.), Treatise on Geomorphology. Academic Press, San Diego, CA, Karst Geomorphology, 6, 157-163. DOI: http://dx.doi.org/10.1016/ B978-0-12-374739-6.00108-1
Denizman, C., 2003: Morphometric and spatial distribution parameters of karstic depressions, Lower Suwannee River Basin, Florida.- Journal of Cave and Karst Studies, 65, 1, 29-35.

Doctor, D. H. \& J. A. Young, 2013: An evaluation of automated GIS tools for delineating karst sinkholes and closed depressions from 1-meter lidar-derived digital elevation data.- In: Land, L., Doctor, D. H., Stephenson, J. B. (Eds.) Proceedings of the 13th Multidisciplinary Conference on Sinkholes and the Engineering and Environmental Impacts of Karst, National Cave and Karst Research Institute, 449-458. DOI: http://dx.doi.org/10.5038/9780979542275.1156

Gams, I., 2000: Doline morphogenetic processes from global and local viewpoints.- Acta Carsologica, 29, 2, 123-138. DOI: https://doi.org/10.3986/ ac.v29i2.453

Kobal, M., Bertoncelj, I., Pirotti, F. \& L. Kutnar, 2014: Lidar processing for defining sinkhole characteristics under dense forest cover: a case study in the Dinaric mountains.- The International Archives of the Photogrammetry, Remote Sensing and Spatial Information Sciences 7, 113-118. DOI: http:// dx.doi.org/10.5194/isprsarchives-XL-7-113-2014

Obu, J. \& T. Podobnikar, 2013: Algorithm for karst depression recognition using digital terrain models. - Geodetski vestnik, 57, 2, 260-270. DOI: http://dx.doi. org/10.15292/geodetski-vestnik.2013.02.260-270

Pardo-Igúzquiza, E., Durán, J. J. \& P. A. Dowd, 2013: Automatic detection and delineation of karst terrain depressions and its application in geomorphological mapping and morphometric analysis.- Acta Carsologica 42, 1, 17-24. DOI: https://doi.org/10.3986/ ac.v42i1.637

Plan, L. \& K. Decker, 2006: Quantitative karst morphology of the Hochschwab plateau, Eastern Alps, Austria.- Zeitschrift für Geomorphologie, NF Suppl. 147, 29-54.

Šušteršič, F., 1994: Klasične vrtače klasičnega Krasa (Classic dolines of classical site).- Acta Carsologica, $23,123-152$. 
Telbisz, T., Dragušica, H. \& B. Nagy, 2009: Doline Morphometric Analysis and Karst Morphology of Biokovo Mt (Croatia) Based on Field Observations and Digital Terrain Analysis.- Hrvatski geografski glasnik, 71, 2, 5-22. DOI: https://doi.org/10.21861/ hgg.2009.71.02.01
Telbisz, T., Látos, T., Deák, M., Székely, B., Koma, Z. \& T. Standovár, 2016: The advantage of lidar digital terrain models in doline morphometry compared to topographic map based datasets - Aggtelek karst (Hungary) as an example.- Acta Carsologica, 45, 1, 5-18. DOI: https://doi.org/10.3986/ac.v45i1.4138 